\title{
Discrimination in hiring based on potential and realized fertility: Evidence from a large-scale field experiment
}

\author{
Citation for published version (APA):
}

Becker, S. O., Fernandes, A., \& Weichselbaumer, D. (2019). Discrimination in hiring based on potential and realized fertility: Evidence from a large-scale field experiment. ROA. ROA Research Memoranda No. 002 https://doi.org/10.26481/umaror.2019002

Document status and date:

Published: 29/04/2019

DOI:

10.26481/umaror.2019002

Document Version:

Publisher's PDF, also known as Version of record

\section{Please check the document version of this publication:}

- A submitted manuscript is the version of the article upon submission and before peer-review. There can be important differences between the submitted version and the official published version of record.

People interested in the research are advised to contact the author for the final version of the publication, or visit the DOI to the publisher's website.

- The final author version and the galley proof are versions of the publication after peer review.

- The final published version features the final layout of the paper including the volume, issue and page numbers.

Link to publication

\footnotetext{
General rights rights.

- You may freely distribute the URL identifying the publication in the public portal. please follow below link for the End User Agreement:

www.umlib.nl/taverne-license

Take down policy

If you believe that this document breaches copyright please contact us at:

repository@maastrichtuniversity.nl

providing details and we will investigate your claim.
}

Copyright and moral rights for the publications made accessible in the public portal are retained by the authors and/or other copyright owners and it is a condition of accessing publications that users recognise and abide by the legal requirements associated with these

- Users may download and print one copy of any publication from the public portal for the purpose of private study or research.

- You may not further distribute the material or use it for any profit-making activity or commercial gain

If the publication is distributed under the terms of Article $25 \mathrm{fa}$ of the Dutch Copyright Act, indicated by the "Taverne" license above, 


\section{Maastricht University ROA}

Discrimination in hiring based on potential and realized fertility: Evidence from a large-scale field experiment

Sascha O. Becker

Ana Fernandes

Doris Weichselbaumer

\section{ROA Research Memorandum}

ROA-RM-2019/2

Researchcentrum voor Onderwijs en Arbeidsmarkt | ROA Research Centre for Education and the Labour Market / ROA 


\section{Discrimination in hiring based on potential and realized fertility: Evidence from a large-scale field experiment}

Sascha O. Becker

Ana Fernandes

Doris Weichselbaumer

ROA-RM-2019/2

April 2019

Research Centre for Education and the Labour Market Maastricht University

P.O. Box 616, 6200 MD Maastricht, The Netherlands

$\mathrm{T}+31433883647 \mathrm{~F}+31433884914$

secretary-roa-sbe@maastrichtuniversity.nl www.roa.nl 


\section{Abstract \\ Discrimination in hiring based on potential and realized fertility: Evidence from a large-scale field experiment*}

Due to conventional gender norms, women are more likely to be in charge of childcare than men. From an employer's perspective, in their fertile age they are also at "risk" of pregnancy. Both factors potentially affect hiring practices of firms. We conduct largescale correspondence test in Germany, Switzerland, and Austria, sending out approx. 9,000 job applications, varying job candidate's personal characteristics such as marital status and age of children. We find evidence that, for part-time jobs, married women with older kids, who likely finished their childbearing cycle and have more projectable childcare chores than women with very young kids, are at a significant advantage vis-àvis other groups of women. At the same time, married, but childless applicants, who have a higher likelihood to become pregnant, are at a disadvantage compared to single, but childless applicants to part-time jobs. Such effects are not present for full-time jobs, presumably, because by applying to these in contrast to part-time jobs, women signal that they have arranged for external childcare.

JEL classification: $\mathrm{C93}, \mathrm{J} 16, \mathrm{~J} 71$

Keywords: fertility, discimination, experimental economics

\author{
Sascha O. Becker \\ Department of Economics \\ University of Warwick \\ Coventry CV4 7AL \\ United Kingdom \\ s.o.becker@warwick.ac.uk
}

\author{
Ana Fernandes \\ Business School \\ Bern University of Applied Sciences \\ Brückenstrasse 73 \\ 3005 Bern \\ Switserland \\ ana.fernandes@bfh.ch
}

Doris Weichselbaumer

Johaness Kepler

University Linz

Altenbergerstrasse 69

4040 Linz

Austria

Doris.Weichselbaumer@jku.at

\footnotetext{
We thank seminar participants at the University of Stirling, the University of Grenoble, the Delhi Indian Statistical Institute, the University of Fribourg, the University of Linz, the Bergen-Stavanger Workshop, the BFH International Conference on Discrimination in the Labor Market, the Annual Congress of the Swiss Society of Economics and Statistics, the Annual Congress of the European Economic Association, and the Annual Congress of the European Association of Labour Economists for insightful comments. We thank Annina Berger, Yashar Blouri, Alexander Seiler and Christiane Koncilja for excellent research assistance. We thank David Neumark for sharing his code on the implementation of Neumark (2012) with us. Financial support by the Swiss National Science Foundation (project no. 100018_140563) and by the ESRC Centre for Competitive Advantage in the Global Economy (grant no. ES/L011719/1) are very gratefully acknowledged. Ethical approval was obtained via Warwick's Humanities and Social Sciences Research Ethics Committee (45/10-11) on 9 July 2011.
} 


\section{Introduction}

Females and males still have very different experiences in the labor market, for example with respect to wages, career paths or assignment of tasks. Differences in terms of pay and career paths are not only the subject of debate in the popular press but are well documented in the academic literature. Goldin (2014) argues that, in the last century, the roles of men and women have greatly converged and that the "last chapter" has been opened for women to achieve full labor market equality. ${ }^{1}$ Even if the situation of women in the labor market has markedly improved over the last decades, the question of why there is a gender asymmetry in the first place has not yet been fully settled.

One possible reason for gender inequality, that receives substantial consideration in the literature, is motherhood and its effects in the labor market. For example, Kleven, Landais and Søgaard (forthcoming) recently showed that, despite considerable gender convergence, in Denmark the presence of children accounts for most of the remaining earnings inequality between men and women in the labor market. Their empirical approach was adopted by Kleven et al. (2019a) who examined child penalties in different countries and found particularly negative effects of children on earnings in the German-speaking countries that are also examined in this study. Sometimes such earnings differences are interpreted as reflecting discrimination. Of course, depending on the data and empirical strategy used, identification problems when interpreting findings on child penalties may occur. Already the early human capital literature (especially the work of Mincer, 1962 and Mincer and Polachek, 1974) emphasized that choices concerning childcare, labor supply, occupation and human capital investments of (future) mothers could generate the same patterns in the data. ${ }^{2}$ As a result, numerous endogeneity issues (e.g., concerning effort at work, selection into work) occur in non-experimental data (e.g., Kunze, 2008) that make the identification of discrimination in wage setting difficult.

In this study, we therefore resort to an experimental setting that allows for full randomization of motherhood status and thereby enables us to clearly identify the occurrence of discrimination in hiring. The results will thus allow us to test whether also demand-side

\footnotetext{
${ }^{1}$ Blau and Kahn (2017), for example, show that the gender wage gap in the US has decreased from 1980 to 2010; however, while in 1980 differences in education played an important role for the difference in wages, this was much less the case in 2010.

${ }^{2}$ Mincer's (1962) path-breaking work on the labour supply of married womens focuses on the number of hours supplied by mothers as a function of children's age (and husband's earnings), i.e. Mincer highlights the issue of compatibility of hours of work with the presence of children of different ages. Mincer and Polachek (1974), apart from deriving different human capital investment and occupational choices depending on expected workinterruptions, stress how families see childcare and labour supply as a joint optimization problem: "the behavior of the family unit implies a division of labor within it." (p.S76).
} 
effects (employer's behavior) play a role in the lower labor market participation rates of women at different stages of family formation. ${ }^{3}$

Discrimination is commonly defined as a situation where individuals of identical productivity are treated differently because of the demographic group to which they belong. "Taste-based" discrimination is rooted in preferences (Becker, 1957), whereas "statistical discrimination" (Phelps, 1972; Arrow, 1973) is considered a rational response of employers to missing information about the applicant's productivity. ${ }^{4}$

In our experiment, we examine two routes how motherhood may encourage statistical discrimination by firms. First, one "risk" (from the employers' perspective) that falls $100 \%$ on females, and not on males, is the risk of pregnancy. This comes with costs to employers who need to find at least temporary replacement for female employees giving birth.

Second, traditional gender norms assign childcare responsibilities primarily to women. Because women have a higher likelihood of dealing with household chores related to childcare - for example they may have to take a day off to take care of a sick child - firms may find hiring females costlier than otherwise similar males. Among females, those with older children may be less likely to have to deal with childcare issues, as older children are in school and/or less likely to suffer from health issues that require parental attention.

To test these possible effects of potential pregnancy as well as childcare, in our study, we look at the hiring chances of women who are in different phases of their family formation. We conduct a correspondence testing experiment in the German-speaking countries, where we send out applications that signal identical productivity but a different family status. Our study relies on the fact that in the countries examined, Germany, Switzerland and Austria, résumés routinely include detailed information about the job candidate's personal characteristics, such as age, gender, marital status and number of children. As such, in our experiment, our thirty-year-old fictitious job candidates are randomly given varying household demographics, ranging from being single and childless or being married and childless, to being married and having two young or two older children. One additional profile provides no information on household composition. Our candidates apply to secretarial and accounting jobs in all three countries, answering job advertisements posted on internet job portals.

We contrast employers' reactions to our candidates in full- and part-time positions, because applicants to full-time jobs implicitly signal that they have childcare arrangements

\footnotetext{
${ }^{3}$ Female labour force participation still falls short of the male labor force participation in most countries. The female-to-male ratio in labor force participation rates is well below 1 in all European countries. In the Germanspeaking countries Germany, Switzerland and Austria, the ratio was 0.806, 0.810 and 0.806, respectively, in 2012. See http://hdr.undp.org/en/content/labour-force-participation-rate-female-male-ratio (accessed $4 \mathrm{March}$ 2019).

${ }^{4}$ See also the discussion in Guryan and Charles (2013).
} 
in place, while those applying to part-time jobs indicate that they are looking for a job that is compatible with childcare duties. Hence, we expect employers to be more concerned about marital status and age of children for those applying to part-time jobs. Our findings are in line with these hypotheses.

Our study includes approx. 9,000 observations (i.e. job applications), covering the largest cities in three different countries, full- and part-time jobs, as well as female and male applicants. Experimental methods to detect discrimination, such as audit studies and correspondence testing, are able to overcome some limitations present in other empirical approaches (see Neumark, 2018). However, Heckman and Siegelman (1993) show that the measurement of discrimination from these studies may be biased if the employer does not observe all determinants of productivity. Neumark (2012) proposes an empirical method to address this problem, which allows for the computation of unbiased estimates of discrimination. Our results are robust to this correction.

The paper proceeds as follows. We next present a literature review. Section 3 describes the institutional context of our study, and section 4 the implementation of our study. In section 5, we present our results. In section 6 , we conclude by discussing the results and their policy implications.

\section{Previous Studies and Differences to the Current Experiment}

Our study is part of the burgeoning literature of field experiments, namely audit studies and correspondence testing (see Bertrand and Duflo, 2017; Neumark, 2018; Baert, 2018; Rich, 2014). In correspondence testing, résumés of applicants that are matched in all relevant qualifications, like schooling and job experience, but which differ with respect to their demographic characteristics, are sent out in response to job advertisements. While quite a few correspondence tests examined sex discrimination more generally in the past, the literature is surprisingly scarce when it comes to the question of fertility. ${ }^{5}$ We next describe those studies in detail.

Firth (1982) conducted a correspondence test for accountants in the UK. He compared the success rates of males and females who were married or single; married individuals were further presented with and without children. The success rates of males were always higher than those of females and the difference widened in the presence of children.

In their correspondence study in France, Duguet and Petit (2005) and Petit (2007) varied the age and family status of their applicants, comprising three types: 25 y.o. and childless, 37

\footnotetext{
${ }^{5}$ As Bertrand and Duflo (2017) write: "A topic of interest for future work would be to apply the correspondence method to measure the extent to which a bias exists against women with children, or against young women who may have children in the future." (p. 325).
} 
y.o., single and childless, and 37 y.o., married with two children. They further compared males and females along those types. The different age groups were meant to indicate different probabilities of future childbearing. The authors found no evidence of discrimination against older women relative to older men. However, the younger female types received callbacks significantly less frequently than the younger men, when applying to highly qualified jobs, which the authors attribute to higher maternity costs in these occupations. Bartoš (2015) used a similar design for his correspondence study, conducted in the Czech Republic. It considered younger ( 25 y.o.) childless males and females, and older (41 y.o.) males and females, who were either childless or had two children instead. All job applicants were married. He found no difference in average callback rates among the younger male and female applicants but older women were preferred to older men. In line with Duguet and Petit (2005), Bartoš (2015) identified weak evidence for a motherhood penalty for younger women, but only when applying to highly qualified positions.

Correll, Benard and Paik (2007) report both on a lab experiment and on a correspondence test, where same-gender applications (both female or both male) with and without children were sent to employers. In both experiments, childless women were preferred to other demographic profiles, and mothers adversely treated compared to fathers. ${ }^{6}$ With a similar design, Bygren, Erlandsson and Gähler (2017) tested parenthood effects in Sweden in one of the most recent studies. However, they did not find any systematic discrimination based on sex or parental status.

A different design was used in the correspondence test of Duguet, Parquet and Petit (2017), who sought to identify a maternity penalty by comparing employer response rates across short- and long-term position within an occupation. They found evidence of a career interruption penalty in one of the three occupations examined.

Baert (2014) provided more indirect evidence compatible with a penalty for potential maternity in an experiment that compared hiring chances of young as well as middle-aged heterosexual and lesbian women. While in his study, lesbian women were preferred to heterosexuals when they were young (and thus in childbearing age) there was no difference for middle-aged women of different sexual orientation. ${ }^{7}$

\footnotetext{
${ }^{6}$ In the field study, childless women were called back 2.1 more times compared to mothers. In the lab experiment, childless women were recommended for hire 1.8 times more frequently than mothers.

${ }^{7}$ Baert, De Pauw and Deschacht (2016) found that hiring discrimination of women was higher when the new job was higher in the job latter than the one currently held. They suggest that because of higher investment costs at higher occupational levels, this may be a manifestation of the career penalty of motherhood.
} 


\section{Differences to Our Study}

As this overview over existing correspondence tests has shown, many previous studies compared women with and without children. However, not knowing more about a woman's family situation than the presence of children, it is difficult to assess her likelihood of pregnancy. Some authors try to address this problem by varying the age of the applicant and thus indicating whether a woman is still in her childbearing years. ${ }^{8}$ However, over the lifecycle also non-fertility related productivity characteristics change, making it difficult to disentangle the effect of fertility in the empirical results.

Also, when motherhood is indicated in a correspondence test, it may be perceived to make childbearing less likely, but it simultaneously signals that the woman possibly has to handle childcare chores. As a result, for an employer it is unclear whether a mother is attractive (because she has already finished her fertility cycle), or unattractive because she may be tied up with childcare issues leading to a lack of focus at work and potential absences.

In this paper, we try to avoid some of the above-mentioned problems. First, we abstain from varying age so as not to introduce any confounding factors affecting invitation rates. All our candidates are therefore of identical age but at different stages of their family formation cycle. Second, we use much more nuanced indicators for potential motherhood and childcare chores. In particular, we work with single candidates and marrieds without kids, who differ in their childbearing probability. Further, we make use of the fact that childcare chores vary with the age of the children - they are especially high for young children who, e.g., are more likely to become sick and in need for immediate care. In our study, we therefore indicate the age of the children to allow employers to assess the level of childcare required.

In addition to extensive indicators describing the family situation, while previous studies focused on full time jobs only, we also exploit differences between full- and part-time jobs. Applying to a part-time job indicates that a woman seeks to reconcile work and family life. We expect that employers offering part-time work find their jobs particularly suitable for women with (older) children, while they are nevertheless worried about maternity leave.

Apart from its novel design, our correspondence study is also the first testing for realized or expected fertility effects in the German-speaking countries. As mentioned, the breadth of information routinely provided in applicants' CVs allows us to inconspicuously place our family situation cues before employers.

\footnotetext{
${ }^{8}$ Also Carlsson and Eriksson (2017) highlight labor market disruptions due to family formation and child care as one reason why women and men may have different age profiles in callback rates. Note that in our study, we hold age constant.
} 


\section{Context of the Current Study}

\section{Job Applications in German-Speaking Countries}

The German-speaking countries provide an ideal context to experimentally analyze discrimination based on (potential) parenthood. First, the application process is rather "traditional": in comparison to other countries, e.g., the UK, few firms work with employerprovided application forms which make testing identical applications in a résumé study impossible. Second, and more importantly, applications provide extensive information on a candidate, not only concerning qualifications but also personal characteristics (Weichselbaumer, 2016). The crucial feature which we rely on is the fact that marital status and number of children are routinely included in the résumés. In our field experiment, we explore this possibility and convey information on the résumé about the age and number of children as well as on the marital status of the applicant. The fact that typical job application packages consist of a cover letter, the résumé, scans of certificates (school, apprenticeships, languages, etc.) and thereby provide detailed information on educational achievements and other human capital characteristics, renders statistical discrimination on other dimensions less likely.

\section{Institutional Features in Austria, Germany and Switzerland}

The countries examined differ with respect to their paternal leave and benefit policies (for details, see Appendix). In Austria and Germany, policies are relatively generous and allow parents to take a break from the duty to work for up to three years without termination of the employment in exchange for the suspension of pay. Different models of paternal benefits can be claimed which cover at least a part of the paternal leave period. In Switzerland, women are only entitled to maternal benefits for 14 weeks after birth and protected from firing until 16 weeks after the birth of a child. ${ }^{9}$

There is a large literature that examines the effect of paternity leave and child care policies (for an overview see Olivetti and Petrongolo, 2017). ${ }^{10}$ However, Kleven et al. (2019b) show (for the setting of Austria) that such policies have little or no effect, at least on penalties with respect to women's wages in the long run. Instead, as the authors illustrate in a different paper (Kleven et al., 2019a), long run child penalties in earnings strongly correlate

\footnotetext{
${ }^{9}$ As a result, labor market participation rates for women with children under 3 years are somewhat higher in Switzerland than in the other countries (see WSI Genderdatenportal, 2018; Bundesamt für Statistik, 2017; Statistik Austria, 2016). According to the OECD Family Database (n.d.), also participation rates of 0-2-year-olds in childcare and pre-school service are higher in Switzerland in 2014 (38\%, Germany: 32.3\%, Austria: 19.2\%).

${ }^{10}$ Of course, family policies may backfire and result in negative labour market outcomes for women in terms of hiring, wages and promotions, as is well documented in the literature. We discuss this issue, with particular consideration of equal pay laws, in the Appendix.
} 
with gender norms. Thus, in their study, the particularly traditional gender norms in the German-speaking countries (they look at Germany and Austria specifically) explain the large child penalties observed there.

Indeed, gender norms are relatively traditional in all three countries examined. For example, data from the 2012 sample of the International Social Survey Program (ISSP) on Family and Changing Gender Roles show that, among those answering the respective questions, in German-speaking countries, respondents feel more strongly than in the EU15 that for women work and family is incompatible. ${ }^{11}$ In Austria, only $1.97 \%$ of respondents think that a mother of children in preschool age should work full-time. In Switzerland, that percentage is $5.33 \%$, and in Germany $14.26 \% .^{12}$ In contrast, in the EU15, the corresponding figure is $17.10 \%$. Looking at whether women should work when their youngest kid is at school, the pattern looks very similar: in Austria, 24.47\% think women should work fulltime in that case, in Germany 30.45\%, in Switzerland $11.47 \%$, and in the EU15 $47.05 \%$.

The conservative gender norms are also reflected in the high rates of female part-time work (in 2015, according to Eurostat: Germany 46.6\%, Switzerland: 60.6\%, Austria: 46.8\%, EU-average: $31.1 \%$ ), which is particularly prevalent for mothers with a partner. For example, in Switzerland, conditional on having a job, $58.6 \%$ of childless, partnered women (age 25 to 54) work full time. This fraction drops to $19.4 \%$ for mothers of similar demographics whose youngest child is 4 to 12 years old, with the remaining $80.6 \%$ working part-time. ${ }^{13}$ These numbers portray part-time as a form of labor market participation strongly associated with the presence of children.

\section{Design of the Experiment}

\section{Family Types}

Because in other countries personal information about an applicant is usually relatively scarce, previous studies typically had to convey fertility information indirectly through varying applicant age and marital status. For example, previous studies inferred fertility discrimination from comparing sex discrimination between old and young applicants. However, age may have different effects by gender independently of fertility. We therefore deliberately held the age of our job candidates constant (at 30 years) and added a broad range of constellations regarding household composition to indicate different probabilities of

\footnotetext{
${ }^{11}$ The EU15 provide a natural comparison for Western European countries. However, note that the ISSP questions were not asked in Greece, Italy and Luxembourg, thus, the "EU15" are only approximated.

${ }^{12}$ Note that the German figures include the former Communist East with more progressive gender norms, while our experiment ran in West-German cities and Berlin. As a result, the respective number is likely to be lower there.

${ }^{13}$ Authors' calculations based on data from the Swiss Federal Statistical Office, table su-d-01.07.05.07 for 2017.
} 
pregnancy and childcare obligations. Our applicants included female and male individuals that were single and childless (default), married and childless, and parents whose two children were either "young" (3 and 5 years) or "old" (7 and 9 years). By differentiating between these types, we sought to isolate different facets of fertility-related costs, in particular by distinguishing between potential fertility (in the comparison of single types with those who are married but have no children) from costs related to child-related chores given realized fertility (comparing between the parents of younger and of older children).

The average fertility rate in Switzerland and Austria is 1.5 and 1.4 in Germany (see UN World Population Prospects, 2015). Consequently, the risk of pregnancy is highest for the married, childless female, small for mothers of two young children (given the low average fertility rate), and close to zero for the mothers of two older children. The latter is because parents of older children are more hesitant to start the child bearing and rearing cycle anew. This is shown for the German Socio-Economic Panel (GSOEP), the richest panel data set in the German-speaking countries, in Figure 1, where we plot the age difference between the $2^{\text {nd }}$ and $3^{\text {rd }}$ child for women who have 3 or more children (for the year 2014). As can be seen, more than $90 \%$ of women have their $3^{\text {rd }}$ child less than 7 years after the $2^{\text {nd }}$. To the extent that employers are aware of this pattern, they will almost certainly assume that a woman with two older children (aged 7 and 9) in our experiment is not going to have a third child.

Comparing parents of younger and older children, the former are more prone to having to deal with child-related chores and illnesses than the latter. Again, this is illustrated with data from the GSOEP in Figure 2, which shows that, in fact, both mothers and fathers of younger children have a higher number of absences due to sick children: the number of days absent because of a sick child are nearly double as high for parents of two young children than for parents of two older children. Mothers, however, have more child-related absences than fathers.

It follows from here that parents of older children appear to be ideal candidates from the point of view of fertility-related costs to the employer: they convey low pregnancy risk and low costs associated with childcare chores. Parents of two younger children likewise have a very low pregnancy risk but potentially face child-related chores. Of course, single women without children may get pregnant in the future, however, at the point of hiring, they have no conventional family obligations at all. For this reason, we have no prior whether single women or women with older children are preferred by employers. We do, however, hypothesize that, first, single and childless candidates outrank the married and childless, as their risk of pregnancy is lower, ${ }^{14}$ and, second, that parents of older children are preferred by

\footnotetext{
${ }^{14}$ According to data from the German Socio-Economic Panel, childless, but married women are likely to have children sooner than childless singles aged 30 .
} 
the employer to parents of younger children who may require more care work. We cannot really sign how employers would rank the married and childless relative to the parents of small children. This depends on how high the costs of a potential pregnancy are perceived to be for the former, relative to the costs of the already present chores with small children, for the latter.

In German-speaking countries, women with children seeking to improve their job opportunities sometimes include a sentence stating that they do not plan to increase their family size. The literal translation of a common statement ("Familienplanung abgeschlossen") used is "family planning completed", however, "family completed" may better capture the meaning. Because mothers of young children may be perceived as yet having some probability to have a third child, in a random subset of this group this sentence family completed was included in their application letter. The goal was to test, whether the inclusion of such statements, sometimes recommended by guidebooks and eagerly discussed in online forums, ${ }^{15}$ has an empirical basis and helps mothers seeking a job, even though from an economic perspective this sentence may be merely considered cheap talk.

Finally, we included one additional "family type" that did not provide any information on a candidate's family situation. The "no information" candidate was incorporated to check whether candidates can avoid discrimination by leaving out information on their family life in their résumé. Alternatively, it could be that firms treat such applications with suspicion. Since previous research has often shown opposing effects of family status for men and women (e.g., Firth, 1982), applications for both sexes were sent out.

\section{Full-Time versus Part-Time Jobs}

While full-time employment is the norm for men, in German-speaking countries, about half of employed women work part-time. In the occupations we consider, accountants and secretaries, $60 \%$ of women work part-time, according to data from the German SocioEconomic Panel. Given the prevalence of part-time employment for women, we sent out applications to both full-time and part-time job advertisements, which the previous literature has not addressed. In the German speaking countries, part-time jobs are often considered an option for women with family obligations to reconcile work and family life. For this reason,

\footnotetext{
${ }^{15}$ Examples for respective recommendations and online debates can be found, e.g., under the following links: https://www.karinleitmueller.at/bewerben-mit-kind, https://essentialtimes.wordpress.com/2011/09/27/bewerbung-3-lebenslauf, https://www.netmoms.de/fragen/detail/bewerbung-schreiben-wie-die-kinder-optimal-einbringen-22842483, http://www.parents.at/forum/archive/index.php/t-57132.html
} 
results may differ for the different activity levels. In our experiment, we consider a job to be full-time if the corresponding occupation rate of the employee is at least $80 \%$.

Regarding potential effects of family type, our hypothesis is that employers will expect parents applying to full-time jobs to have arranged proper childcare, e.g., via grandparents or other child-minders, as otherwise they would not be able to consider a full-time job. If such arrangements are in place, parents are less likely to be absent from work if a child is sick. In contrast, parents applying to part-time jobs signal that they want to reconcile work and family life. Here, in all likelihood, in case of a sick child, parents themselves will have to look after their sick children, creating days of absence at work.

We therefore expect any differences in callback rates between parents with older children and parents with younger children (who have to deal with more illnesses) to be more pronounced for part-time jobs than for full-time jobs. Similarly, any potential difference in callback rates between childless singles and childless, but married, applicants is also likely to be larger for part-time jobs because an employer might take an application of a married woman to a part-time position as a signal of an intended pregnancy.

\section{Other Characteristics of the Application Material}

In the German speaking countries, not only cover letters and a résumé are included in an application, but also certificates and school reports with degree and grade information. These were prepared to signal the relevant qualification in a good quality. Applicants were currently employed with their second employer. To allow us to send two applications to each firm, two templates were constructed which provided identical information with respect to human capital but which differed in aspects irrelevant to productivity (layout of the application, order of documents, birthplace, specific school attended of the same branch, etc.).

We applied to secretarial and accounting jobs, because clerical jobs cover a large fraction of female employees in the country investigated and are therefore empirically relevant. We picked female-dominated jobs because we are interested in whether or not fertility aspects matter in occupations that are generally open to women. ${ }^{16}$ Indeed, a potentially high average acceptance rate of women in those jobs is not incompatible with preferential behavior toward female candidates credibly signaling to have low fertility risk in detriment of others unable to provide such a signal. Additionally, the labor demand in these jobs was large enough, so

\footnotetext{
16 In the German-speaking countries, it is difficult to identify male-dominated jobs with homogeneous qualification requirements and a large enough stream of vacancies, which is a precondition for conducting a correspondence test.
} 
that a reasonably large data set could be collected, and job-profiles in these occupations are relatively homogeneous, thus allowing us to work with standardized applications. Finally, both occupations have a substantial number of full and part-time jobs, allowing us to study and compare potential discrimination in both.

Applications were sent to job vacancies in the largest cities in Germany (Berlin, Hamburg, Munich, Cologne, Frankfurt and Stuttgart), the German-speaking part of Switzerland (Bern, Zurich and Basel), and Austria (Vienna).

\section{Procedure}

Data collection comprised the period March 2013-June 2015. ${ }^{17}$ Over this period of roughly two years, we sent out application packages consisting of a cover letter, a résumé, documents from the relevant educational institutions with degree and grade information, as well as reference letters. For "high quality" applicants, we also included IT and language certificates. In all cases, two applications with different templates were sent to each company. We randomized the "family/fertility type", our treatment variable, but also other elements in the résumé such as the picture and name of the candidate as well as the general template of the application.

Applications were sent out to all suitable job advertisements posted in online job portals. Suitability meant that some filtering was done to remove, for example, job agencies, likely to keep our profiles in their records for at least some time, or firms that were already included in our sample and would likely detect the experiment. Answers from the employers were received by email, mobile phone or regular mail (rejections always came by email or regular mail but invitations sometimes were conveyed in the form of voice messages on the answering machine). Whenever our candidates received an invitation to an interview, in order to minimize costs for the employer, we quickly declined alleging that another offer had materialized in the meantime. ${ }^{18}$

\footnotetext{
${ }^{17}$ Data collection started in March 2013, with Switzerland, and was soon extended to Germany, in April that year. Data collection for Austria (Vienna) was initiated in June 2014. Austria was not a country in our initial research plan but the similarities in the job application procedure suggested that an extension to that country would serve as a useful comparison to the other two German speaking countries. Regarding 2015, data were essentially only being collected for Austria, though one city in Germany (Berlin) and one in Switzerland (Zurich) were also included in the continuation of the study to provide a benchmark to Austrian data. Despite data being collected for almost a year for Austria, we were not able to gather a high number of observations.

${ }^{18}$ Those critical of correspondence studies point out the costs to employers of having to deal with "fake applications' which is why we decline invitations for job interviews right away. Yet, we would like to highlight that the German Federal Antidiscrimination Agency (2011) explicitly validates the legality of correspondence testing as a means to detect discrimination.
} 


\section{Results}

Our sample comprises nearly 9,000 observations, a large sample size compared to much of the existing literature related to our study. ${ }^{19}$ The variable callback measures whether an applicant was invited for an interview.

Table 1, panel A illustrates the unconditional probability of receiving a callback for applications to full-time jobs and shows the marked differences between males and females. While for females, the unconditional probability of receiving a callback is $19.62 \%$, it is only $11.53 \%$ for males. When these numbers are disaggregated by occupation, men's callback rate for secretarial jobs declines to $7.11 \%$ whereas the female rate becomes $16.45 \%$. In accounting jobs, men receive a callback $16.72 \%$ of the time, whereas the female callback rate is $23.58 \%$. The same pattern of female advantage is found at the country level. These sex differences in callback rates resonate with other studies surveyed in Riach and Rich (2006) and Rich (2014) concerning discrimination of men in female dominated jobs, and of women in male dominated activities. ${ }^{20}$ One possible explanation for these findings is employer selection based on gender stereotyping (Weichselbaumer, 2004).

Turning to the different family types, for both female and male applicants, the differences in callback rates do not seem to be large for applications to full-time jobs. For women, they range from $18.36 \%$ (married, 2 young kids) to $20.58 \%$ (single, no kids). ${ }^{21}$

Table 1, panel B shows callback rates for applications to part-time jobs. Interestingly, for women average callback rates are nearly identical to those for full-time jobs $(19.22 \% \mathrm{vs}$. $19.62 \%) .{ }^{22}$ However, there is substantially more variation across family types, now ranging from $13.11 \%$ for those who are married with no children to $27.18 \%$ for those who are married with 2 old children.

\footnotetext{
${ }^{19}$ We originally collected an even richer set of profiles, but being concerned about multiple measures potentially related to the same information, we focus on the profiles described in the previous section.

${ }^{20}$ Nonetheless, there is no complete uniformity in occupations concerning whether discrimination negatively affects males or females. While callback decisions in secretarial jobs tend to disproportionately favour females, in accounting positions males are sometimes preferred (see, e.g., Table 4 in Rich, 2014). In Weichselbaumer (2004), for example, while women are strongly preferred to males in secretarial jobs, in accounting jobs, males and females are called back at similar rates.

${ }^{21}$ For the subset of those who were married with 2 young kids and who indicated in the cover letter to have their "family completed", the callback rate was somewhat higher (24.1\%). As we will see in the regression analysis, though, the difference between applications with and without this sentence is not statistically significant.

${ }^{22}$ For men, callback rates are substantially lower in part-time than full-time jobs ( $7.26 \%$ vs. $\left.11.53 \%\right)$.
} 


\subsection{Multivariate Analysis}

In the following, we present our results from a variety of OLS regressions of the dependent variable "callback" on a broad set of controls. ${ }^{23}$ In addition to the treatment variables (fertility/family types), all regressions incrementally include controls for variables like city (Bern, Zurich, Basel, Hamburg, Berlin, Munich, Frankfurt, Cologne, Stuttgart, Vienna), time (quarter and year) of application sent, application characteristics and firm characteristics. Application characteristics include the occupation (secretary vs. accountant), the sex of the applicant, the template and the picture used in a specific application, the quality of the application (an application was of particularly high quality, when IT and English language certificates were included), and the quality of the fit of our profile to a particular vacancy. ${ }^{24}$ The firm characteristics capture the sector (public sector, trade, manufacturing and services sectors), the range of business activity (local/regional, national, international), the firm size as given by the number of employees (seven dummy variables ranging from " 1 to 20 " to "more than 1000"), whether the firm was more than $20 \mathrm{~km}$ away from the applicant's address (distance from residence to the workplace), as well as whether the firm has an explicit antidiscrimination policy (according to its website). Descriptive statistics are given in Table A.1.

\section{Full-Time Jobs}

\section{No Effects of Family Status and Family Type}

Table 2 shows the results for the pooled sample of women (i.e., covering all countries), where we regress the outcome dummy "callback" on the treatment variables (married w/o kids, married with two young kids, married with two old kids, no info, default: single w/o kids). We start with regressions that do not include any control variables. As a result, column 1 essentially reproduces the descriptive statistics from Table $1 .{ }^{25}$

In column 2, we split the category "individuals with two young kids" into two: those who did or did not include a sentence in the cover letter that they have their "family completed", i.e. are not intending to have additional children. We formally test the equality of these two coefficients by a t-test (p-value: 0.19). Based on this, we cannot reject the Null-hypothesis

\footnotetext{
${ }^{23}$ Results using Probit or Logit models (not shown) are very similar, as is common when the average of the outcome variable is outside the tails of the $[0,1]$ interval.

${ }^{24}$ Three dummy variables reflected how well the set of fixed skills possessed by our applicants matched the requirements of each specific job ad that we answered. "Good fit" is a dummy variable coded as one when all the job requirements were met by our candidates; if our candidates' qualifications did not fully meet the advertisement specifications, they were coded as having an "average fit" (when only minor requirements were not met), or as being a "bad fit" (when one crucial or two or more minor requirements were not satisfied).

${ }^{25}$ Throughout our analysis, standard errors are clustered at the company level.
} 
that they are equal. Thus, adding a sentence on "family completion" does not lead to significantly different treatment of female applicants with two young kids who apply to fulltime jobs.

Subsequent columns control for increasingly richer sets of covariates. Columns 3 and 4 add city dummies, columns 5 and 6 add application characteristics, including year and quarter dummies, columns 7 and 8 add firm characteristics. ${ }^{26}$

Our first important result from the multivariate analysis is the absence of statistically significant effects associated with family type for applications to full-time jobs: employers do not seem respond to the family situation of job applicants. Given that there is no clear evidence of discrimination based on one's family situation in odd-numbered columns, it does not surprise that the statement on one's family completion does not matter for callback probabilities (even-numbered columns).

\section{Part-Time Jobs}

Part-time jobs allow women to reconcile gender norms, which assign to them the responsibility for child care, with work life. For this reason, family type may affect hiring behavior of firms differently when part-time jobs are concerned. In particular, women without children applying for a part-time job may be perceived as planning to become mothers soon - especially if they are married. We also expect differences concerning the outcomes of mothers: While mothers applying to full-time jobs must have external childcare arranged, this is not necessarily true for mothers in part-time jobs. Thus the difference between mothers of old children and mothers of young children is expected to be larger in part-time jobs, because the former are less likely to have to deal with urgent childcare tasks, e.g., when children are sick. In the following, we provide results for part-time jobs (corresponding to a work time of less than $80 \%$ ).

\section{Effects of Family Status and Family Type}

Table 3 shows the results of our multivariate analysis for part-time jobs. The design of the table follows Table 2, with the first two columns showing results without control variables, whereas subsequent columns successively add more covariates.

Being married and childless is associated with a 4-6 percentage points lower callback rate, marginally significant in half of our specifications, compared to being single and childless. This finding is consistent with the idea that employers predict that children are

\footnotetext{
${ }^{26}$ Throughout, in even-numbered columns, the t-tests of equality of coefficients with and without the "family completed" statement, have p-values larger than 0.1 , indicating that equality of coefficients cannot be rejected at the $10 \%$ level.
} 
imminently awaited, and that the employer may want to avoid pregnancy related costs. Women with two younger children and those with no information on family type do not significantly differ from the reference group in terms of callback rates. According to our even-numbered specifications, if anything, a married woman with young kids is hurt by the statement that she has already completed her family - possibly because it unwantedly draws attention to potential future childbearing. ${ }^{27}$ However, we recommend caution with respect to this result, given that the sample of women with such a statement is very small.

A 30-year old mother of two old children, on the other hand, does not only convey the message that she is unlikely to have further children, but also that her children are unlikely to require immediate childcare, for example when being sick. Companies appear to welcome that message, as callback rates are significantly higher by $8-9$ percentage points, compared to single and childless women.

Given average callback rates of $19.22 \%$ for applications to part-time jobs, our results suggest substantial differences across family types, with a spread of 12-15 percentage points between married and childless women compared to those who are married with two older kids.

\section{Country-Specific Analyses}

Since callback differences by family status have been found only for part-time, it is fair to ask whether results are driven by one specific country or are common to all three Germanspeaking countries in our analysis. Table 4 presents the respective results. ${ }^{28}$ It shows the richest set of specifications (mirroring columns 7 and 8 of Table 3) for Germany, Switzerland, and Austria, separately. The table illustrates that results go in the same direction (even if less significant due to the smaller sample sizes) across the three countries, with married, but childless women differing markedly in callback rates from women with two older children. This is the case even though all three countries have clear anti-discrimination laws where differential treatment based on sex or expected motherhood is forbidden.

\section{Secretaries vs. Accountants}

Throughout, we pool applicants to secretary and accountant jobs and include a dummy for secretaries (accountant being the default). When we split the sample by occupation (not reported), we find the same ordering of family types for applications to part-time jobs:

\footnotetext{
${ }^{27}$ For specifications 4 and 6 , the difference of coefficients is marginally significant $(p=0.08, p=0.07)$.

${ }^{28}$ Table A. 2 shows country-specific results for full-time jobs. Apart from the small sample size for Austria, the only thing to note is that results across all three countries are very similar to the pooled analysis: we find no evidence for a systematic difference in callback rates across family types in any of the three German-speaking countries.
} 
married and childless women have lower callback rates than single childless women, and women with two old kids perform better than women with two young children. Both in terms of point estimates and in terms of statistical significance, results are somewhat stronger for accountants than for secretaries, particularly concerning the difference between single women and married women with no kids. This is consistent with the idea that secretaries can probably be more easily replaced than accountants: first, firms might have more secretaries than accountants, making the latter more pivotal; second, accountants have more specific job-related human capital which is harder to replace at short notice, should a female accountant go on maternity leave or be absent from work.

\section{Male Candidates}

Throughout the paper, our focus is on female applicants. Still, male candidates are an interesting point of comparison in our two female-dominated occupations. We show the respective results for full-time, where we have more data, in Table A.3.

As we pointed out before, callback rates for men are substantially lower than for women. However, looking at family types, there is no discernible pattern for men neither for full-time nor part-time jobs (not shown), i.e. firms do not seem to consider information on a male applicant's family important enough to make use of it for their hiring decisions.

\subsection{Effects of the Variance of Unobservable Determinants of Productivity}

Heckman and Siegelman (1993) first showed that differences in the variance of unobservable productivity determinants may bias the measurement of discrimination: Even in the absence of taste-based discrimination, without group differences in average unobservable characteristics, different variances in unobservable drivers of productivity may lead to differential treatment due to statistical discrimination.

Notably, in a correspondence study, the direction of this "variance effect" depends on the quality level of the applicants, i.e., their observable productivity characteristics, set by the experimenter. For example, if the quality level of the fictitious candidates is low compared to their real-life competitors, an applicant from the group with the higher variance of unobservable characteristics will be treated more favourably by firms, because he or she will more likely pass the companies' quality threshold. The reverse is true if the applicants are of high-quality. 
Neumark (2012) developed a method to measure the "variance effect" and obtain an unbiased estimate of discrimination (see also Neumark and Rich, 2019), which we apply. ${ }^{29}$ Given that in the linear probability model, for part-time jobs we found the most marked differences between married women without kids and married women with older kids, we focus on the comparison of these groups in the following (thus the smaller sample size). As Table 5, column 1, illustrates, for part time jobs, in the basic probit, married women with older children are 13 percentage points more likely to receive a callback than married women without children. This result is similar to the findings from the linear probability model. However, the Neumark decomposition illustrates that this effect is actually underestimated. Married women with older children have a lower standard deviation of unobservable vis-à-vis married women without children and suffer from a negative "variance effect". Apparently, the relatively low quality of the experimental candidates in this setting has led to a relative advantage for the applicant from the higher variance group (the married women without children). Bare of this "variance effect", the "unbiased level effect" favoring the mother of older children is even higher than in the linear probability model (25 percentage points) and strongly significant, thus confirming more favourable treatment of women who have completed fertility (and who have little urgent childcare chores), or unfavourable treatment of women who likely start childbearing, respectively.

As before, we do not find any differences between candidates for full-time jobs. This finding thus reinforces the conclusion from the linear probability model that family composition does not appear to be a factor taken into consideration by employers when making callback decisions for those jobs.

\section{Discussion and Conclusion}

In our large-scale correspondence study, we looked at discrimination in hiring in femalefriendly professions. We deliberately picked female-friendly professions (secretaries and accountants) to avoid comparing women to men in occupations where they may be considered less productive to begin with. This allowed us to focus on differences in callbacks for a variation of female applicants with different family profiles.

Our study has several distinguishing features that set it apart from the small literature on what we call "fertility discrimination in hiring". We indicate the probability of childbearing as well as childcare chores by varying information on marriage, presence on children and age of children, while holding applicant age and past work experience constant. The reason

${ }^{29}$ Neumark and Rich (2019) use this method to re-assess several published studies of labour market discrimination. They find that with the proposed correction, just over half of the estimates of discrimination fall to near zero, become statistically insignificant, or change sign. 
why this can be done inconspicuously is that in the German-speaking countries, which we examine, this information is routinely given on résumés. Different from earlier research, we send applications not only to full-time, but also to part-time jobs.

Our conjecture is that employers consider childless, but married women, at particular "risk" of becoming pregnant. This is in line with stylized facts based on micro data from the German Socio-Economic Panel (GSOEP) showing that married but childless women are more likely to have children than childless singles. Thus, we hypothesize that married women without children are less likely to receive a callback than single women. At the same time, mothers of two young children are more likely to suffer from child-related absences than mothers of two older children. Also this stylized fact is based on GSOEP data. We therefore hypothesize that mothers of two older children receive more callbacks than mothers of young children.

Concerning the difference between candidates applying to full- and part-time jobs we argue the following: Applicants to part-time jobs convey a desire to reconcile family duties with work. In contrast, applicants to full-time jobs signal that, independent of their family situation, they "must have" childcare arrangements in place, because otherwise they could not reconcile a full-time job with the logistics of picking up children from daycare or school. As a result, we expect differences in callbacks between mothers of old children vis-à-vis mothers of young children to be more pronounced for part-time work. For part-time, we also expect stronger differences between single and married women without children. The reason is that a married, but childless woman, who applies to a part-time job may be considered at a particular "risk" of becoming pregnant.

We find that for applicants to full-time jobs, fertility-related information actually does not result in different callback rates. ${ }^{30}$ Apparently, employers rely on full-time applicants having their family-related issues dealt with. This finding is in line with a recent study by Bygren, Erlandsson and Gähler (2017) for Sweden and suggests that discrimination in full-time jobs is not based on considerations of potential family formation or family obligations.

However, in line with our hypotheses, we find stronger differences looking at applicants to part-time jobs, where there is substantial variation in callback rates. Married, but childless women applying to part-time jobs have the lowest callback rates, and women with two older children the highest. The gap in callback rates between these two groups is 14 percentage points, which is substantial given average callback rates of 19 percent for part-time jobs. We interpret these findings as presence of substantial hiring discrimination based on realized and

\footnotetext{
${ }^{30}$ We would like to stress that despite our large sample, the fact that, for full-time jobs, differences in callback rates between family types are not statistically significant, does not preclude that there are differences, as confidence intervals are compatible with some differences across types.
} 
expected fertility for part-time jobs - a possibly surprising result, since these jobs are typically meant to be particularly family-friendly.

One additional aspect we study is whether mothers of small children can signal to employers that they are not intending to have additional children. In German-speaking countries, it is common to use a statement saying "family completed" to signal that no further pregnancies are planned. We do not find differences in callback rates between mothers with two young children who use such statement in their cover letters compared to those who do not, on conventional statistical levels. This finding is consistent with the idea that employers consider such statements as cheap talk, however, given the relatively small sample of observations with such a statement, this interpretation has to be taken with caution.

A lot of progress has been made over the last decades to help equal treatment of women in the labour market. Although employers' concerns related to realized and expected motherhood is often believed to be the key driver for women's inferior labor market chances, our findings do not provide evidence that such a mechanism persists in full-time jobs in the German-speaking countries today. However, maybe unexpected for many, our results for part-time jobs illustrates that employers are not fully immune to considering potential or realized motherhood in female applicants, even in female-friendly occupations. 


\section{References}

Arrow, Kenneth J. (1973) "The Theory of Discrimination“ in: Orley Ashenfelter and Albert Rees (eds.) Discrimination in Labor Markets, Princeton, NJ: Princeton University Press, 3-33.

Baert, Stijn (2014) “Career Lesbians. Getting Hired for Not Having Kids?” Industrial Relations Journal 45 (6), 543-561.

Baert, Stijn (2018) "Hiring Discrimination: An Overview of (Almost) All Correspondence Experiments Since 2005" in: S. Michael Gaddis (ed.) Audit Studies: Behind the Scenes with Theory, Method, and Nuance, Springer International Publishing.

Baert, Stijn, Ann-Sophie De Pauw, and Nick Deschacht (2016) "Do Employer Preferences Contribute to Sticky Floors?” Industrial and Labor Relations Review 69 (3), 714-736.

Bartoš, Vojtěch (2015) "(Ne)diskriminace žen při žádosti o zaměstnání v důsledku mateřství: Experiment", IDEA study 1/2015.

Becker, Gary S. (1957) The Economics of Discrimination, Chicago: University of Chicago Press. Bertrand, Marianne and Esther Duflo (2017) "Field Experiments on Discrimination" in: Abhijit Banerjee and Esther Duflo (eds.) Handbook of Economic Field Experiments, North Holland: Elsevier, 309-393.

Blau, Francine D. and Lawrence Kahn (2013) "Female Labor Supply: Why Is the United States Falling Behind?" American Economic Review: Papers \& Proceedings 103 (3), 251-256.

Blau, Francine D. and Lawrence Kahn (2017) "The Gender Wage Gap: Extent, Trends, and Explanations" Journal of Economic Literature 55 (3), 789-865.

Bundesamt für Statistik (2017) "Familien in der Schweiz. Statistischer Bericht 2017”.

Bygren, Magnus, Anni Erlandsson and Michael Gähler (2017) "Do Employers Prefer Fathers? Evidence from a Field Experiment Testing the Gender by Parenthood Interaction Effect on Callbacks to Job Applications" European Sociological Review 33 (3), 337-348.

Carlsson, Magnus and Stefan Eriksson (2017) "The Effect of Age and Gender on Labor Demand" Linnaeus University Working Papers, 2017:4.

Correll, Shelley J., Stephen Benard and In Paik (2007) "Getting a Job: Is There a Motherhood Penalty?” American Journal of Sociology 112 (5), 1297-1339.

Datta Gupta, Nabanita, Nina Smith and Mette Verner (2008) "The Impact of Nordic Countries' Family Friendly Policies on Employment, Wages, and Children" Review of the Economics of the Household 6, 65-89.

Duguet, Emmanuel, Loic du Parquet and Pascale Petit (2017) "Hiring Discrimination Against Women: Distinguishing Taste-Based Discrimination from Statistical Discrimination" TEPP WP 2017-11.

Duguet, Emmanuel and Pascale Petit (2005) "Hiring discrimination in the French financial sector: an econometric analysis on field experiment data" Annales d'Économie et de Statistique 78, 80-101.

Eurostat (2019, March 11). Teilzeitbeschäftigung als Prozentsatz der gesamten Beschäftigung, nach Geschlecht und Alter (\%). Retrieved March 12, 2019, from http://appsso.eurostat.ec.europa.eu/nui/submitViewTableAction.do 
Firth, Michael (1982) “Sex discrimination in job opportunities for women” Sex Roles 8 (8), 891-901.

German Federal Antidiscrimination Agency (2011) Die Anwendbarkeit von Testing-Verfahren im Rahmen der Beweislast §22 Allgemeines Gleichbehandlungsgesetz.

Goldin, Claudia (2014) "A Grand Gender Convergence: Its Last Chapter" American Economic Review 104 (4), 1091-1119.

Guryan, Jonathan and Kerwin Kofi Charles (2013) "Taste-based or Statistical Discrimination: The Economics of Discrimination Returns to its Roots" The Economic Journal 123(572), F417-F432.

Datta Gupta, Nabanita; Nina Smith, and Mette Verner (2008) “The impact of Nordic countries' family friendly policies on employment, wages, and children" Review of Economics of the Household $6(1), 65-89$.

Heckman, James and Peter Siegelman (1993) "The Urban Institute Audit Studies: Their Methods and Findings" in: Michael Fix and Raymond J. Struyk (eds.) Clear and Convincing Evidence: Measurement of Discrimination in America, Washington, D.C.: The Urban Institute Press, 187-258.

Kleven, Henrik, Camille Landais and Jakob Egholt Søgaard (forthcoming) "Children and Gender Inequality: Evidence from Denmark", American Economic Journal: Applied Economics.

Kleven, Henrik, Camille Landais, Johanna Posch, Andreas Steinhauer and Josef Zweimüller (2019a) "Child Penalties Across Countries: Evidence and Explanations" mimeo.

Kleven, Henrik, Camille Landais, Johanna Posch, Andreas Steinhauer and Josef Zweimüller (2019b) "The Impact of Family Policies on the Dynamics of Gender Inequality" mimeo.

Kunze, Astrid (2008) "Gender Wage Gap Studies: Consistency and Decomposition" Empirical Economics 35, 63-76.

Mincer, Jacob (1962) "Labor Force Participation of Married Women: A Study of Labor Supply" in: Universities-National Bureau Committee for Economic Research (eds.) Aspects of Labor Economics, Princeton University Press.

Mincer, Jacob and Solomon Polachek (1974) "Family Investments in Human Capital: Earnings of Women" Journal of Political Economy 82 (2,2), S76-S108.

Neumark, David (2012) "Detecting Discrimination in Audit and Correspondence Studies" Journal of Human Resources 47 (4), 1128-1157.

Neumark, David (2018) "Experimental Research on Labor Market Discrimination" Journal of Economic Literature 56 (3), 799-866.

Neumark, David and Wendy A. Stock (2006) "The Labor Market Effects of Sex and Race Discrimination Laws" Economic Inquiry 44 (3), 385-419.

Neumark, David and Judy Rich (2019) "Do Field Experiments on Labor and Housing Markets Overstate Discrimination? A Re-examination of the Evidence" Industrial and Labor Relations Review 72(1), 223-252.

OECD Family Database (n.d.) "Enrolment in Childcare and Pre-School" retrieved from http://www.oecd.org/els/family/database.htm\#labour_market [06.06.2018]. 
Olivetti, Claudia and Barbara Petrongolo (2017) "The Economic Consequences of Family Policies: Lessions from a Century of Legislation in High-Income Countries," Journal of Economic Perspectives 31, 205-230.

Petit, Pascale (2007) "The Effects of Age and Family Constraints on Gender Hiring Discrimination: A Field Experiment in the French Financial Sector" Labor Economics 14, 371-391.

Phelps, Edmund S. (1972) "The Statistical Theory of Racism and Sexism" American Economic Review 62 (4), 659-661.

Riach, Peter A. and Judy Rich (2006) "An Experimental Investigation of Sexual Discrimination in Hiring in the English Labor Market" Advances in Economic Analysis \& Policy 6 (2), 1-20.

Rich, Judy (2014) "What Do Field Experiments of Discrimination in Markets Tell Us? A Meta Analysis of Studies Conducted since 2000" IZA Discussion Paper 8584.

Statistik Austria (2016) "Mikrozensus - Arbeitskräfteerhebung 2016" retrieved from https://www.statistik.at/web_de/statistiken/menschen_und_gesellschaft/soziales/genderstatistik/vereinbarkeit_von_beruf_und_familie/index.html (16.10.2018).

United Nations, Department of Economic and Social Affairs, Population Division (2015) World Population Prospects: The 2015 Revision, Volume II: Demographic Profiles (ST/ESA/SER.A/380).

Vaccaro, Giannina (2018) "Using Econometrics to Reduce Gender Discrimination: Evidence from a Difference-in-Discontinuity Design" Working Paper.

Weichselbaumer, Doris (2004) "Is It Sex or Personality?" Eastern Economic Journal 30 (2), 159186.

Weichselbaumer, Doris (2016) "Discrimination against Female Migrants Wearing Headscarves" IZA Discussion Paper 10217.

WSI Genderdatenportal (2018) "Erwerbstätigenquote nach Elternschaft und Alter der Kinder 2017" retrieved from https://www.boeckler.de/53497.htm (16.10.2018). 


\section{Appendix}

\section{Parental Leave and Equal Pay Policies in the German-Speaking Countries}

In Germany, paternity leave may be enjoyed by both parents. There is an initial period of paid leave covering the first 12 months of the baby's life (possibly 14 if both parents take it). The leave can however be extended without pay up to 3 years. Under some conditions (including company size and length of the employment contract), there is the possibility to work part-time during the leave. Employment is protected for the entire duration of the parental leave, and parents have the right to return to their position before birth or to another one with identical conditions.

In Austria, parental leave can last up to two years to be (possibly) shared by both parents. In addition to the possibility of working part-time during the leave, a unique feature of the Austrian system is the right to work part-time after the leave, up to the child's $7^{\text {th }}$ birthday. Income is partially covered during the leave and parents get to choose from a menu of different compensation possibilities and leave duration. As in Germany, salary payments during the leave are not borne by the employer. Financing of the parental leave systems across the three countries in our sample is based on contributions that all employers and employees pay regularly (wage deductions on employees and wage-related taxes born by companies).

Switzerland offers the shortest period of maternity leave, 14 weeks. Mothers receive $80 \%$ of their former salary during the leave. The employer has the option to pay the remaining $20 \%$ or to prolong the leave for another 2 weeks, to a total of 16 . The law does not require the employer to accept a reduction in the workload upon the return of the mother, and the company is free to terminate the employment upon the end of the leave without any restrictions. Unlike Austria and Germany, there is no leave for fathers, though unions and companies usually foresee 1 to 3 days of vacation when the child is born and the possibility to take 1 to 3 weeks of unpaid vacation. Given the short work disruption, the Swiss system is seemingly the least intrusive - unless any disruption is similarly costly to companies, irrespective of length (e.g., employers can hire replacement personnel for long-term, but not for short-term interruptions).

Costs from the compliance to the regulations above and adapting company practices to the family situation of employees as a result is one argument often heard underlying potential statistical discrimination against women in fertile age. Employers may react by paying women lower wages, or simply by not hiring them. Indeed, the possibility that family 
policies may backfire and result in negative labour market outcomes for women in terms of hiring, wages and promotions is well documented in the literature. ${ }^{31}$

All three German-speaking countries have had legal provisions for gender equality in pay ('equal pay for equal work') for decades. ${ }^{32}$ For example, all countries have ratified the ILO Equal Remuneration Convention (C100). They have also ratified the Discrimination Convention (C111) and the UN Convention on the Elimination of All Forms of Discrimination Against Women. However, because equal pay has received increasing scrutiny in recent decades, it is possible that employers resort to hiring instead of wage discrimination, as the former is particularly likely to go unnoticed. ${ }^{33}$

\footnotetext{
${ }^{31}$ See e.g. Datta Gupta, Smith and Verner (2008) for a discussion of the impact of the generosity of family policies in Nordic countries on female employment and wages, Neumark and Stock (2006) on the effects of state equal pay laws in the US on the relative employment of black and white females, and Blau and Kahn (2013) for an international comparison of the effects of family policies on labor force participation and other labor market outcomes of American women versus those in other countries.

${ }^{32}$ In Germany, Article 3 of the 1949 Constitution ('Basic Law') provides for equal treatment of all citizens across essentially all areas of life. In Austria, the 1979 Act on Equal Treatment on Men and Women has the same purpose. In 1981, gender equality and equal pay for equal work were written into the Swiss constitution.

${ }^{33}$ In 2006, the Swiss Federal Office for Gender Equality created a tool to assist companies in evaluating whether or not they were paying equal wages for identical work. This policy tool is called logib and allows companies to resort to a widely used spreadsheet software to run a regression and evaluate the fairness of their pay structure by checking the sign and statistical significance of the coefficient on a gender dummy. Germany (with logib-d) and Austria (with www.gehaltsrechner.gv.at) soon followed suit in devising and implementing similar policy tools. Vaccaro (2018) evaluated the success of the Swiss logib in reducing the gender wage gap (GWG) and found that this policy tool has led to a decline of 3.5pp in the unexplained part of the GWG, but of only $1.5 p p$ on the raw wage gap.
} 


\section{Figures}

Figure 1: Age Difference Between 2nd and 3rd Child

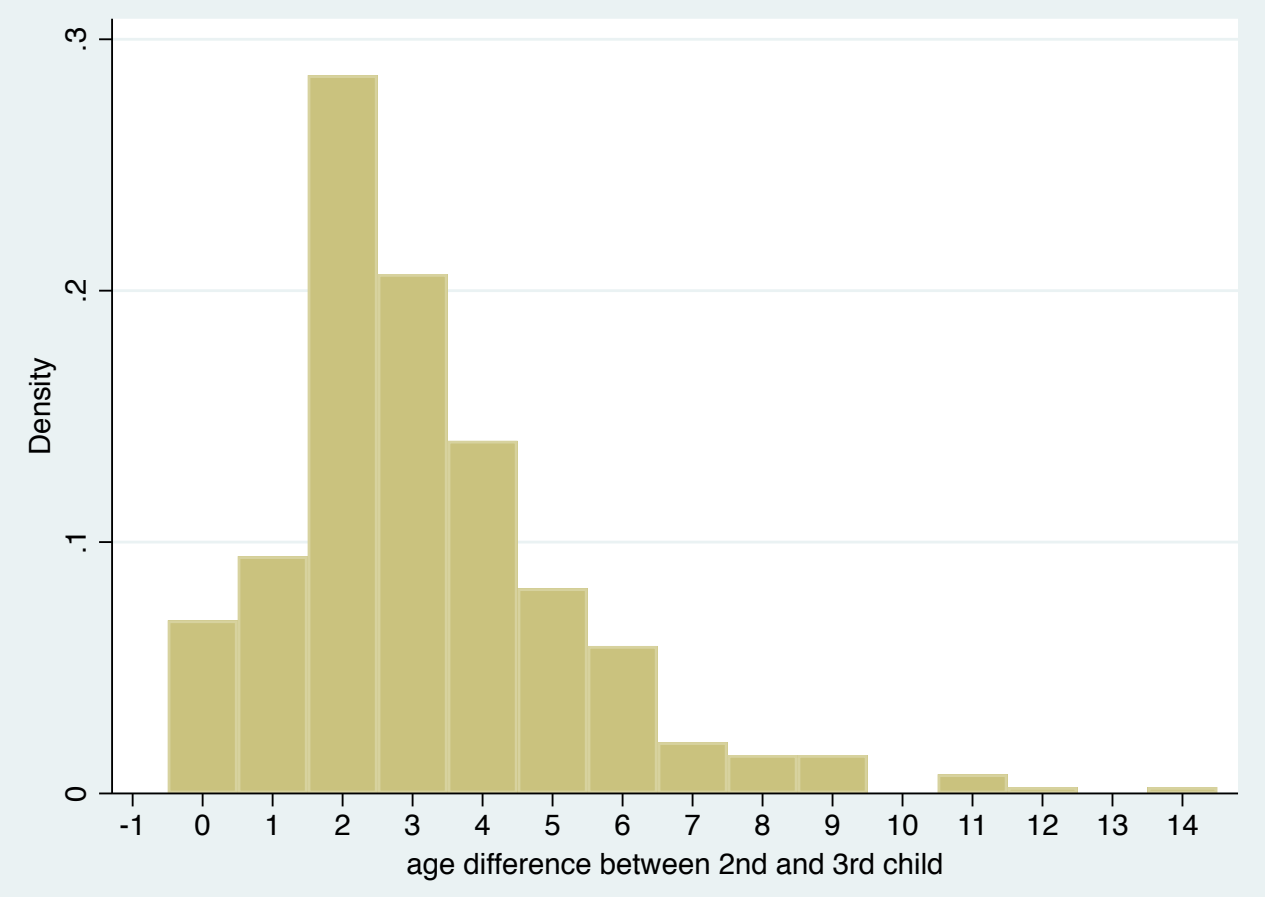

Notes: Data from Socio-Economic Panel (GSOEP). Displaying age difference between $2^{\text {nd }}$ and $3^{\text {rd }}$ child for mothers with at least own 3 children. 
Figure 2: Days Absent at Work

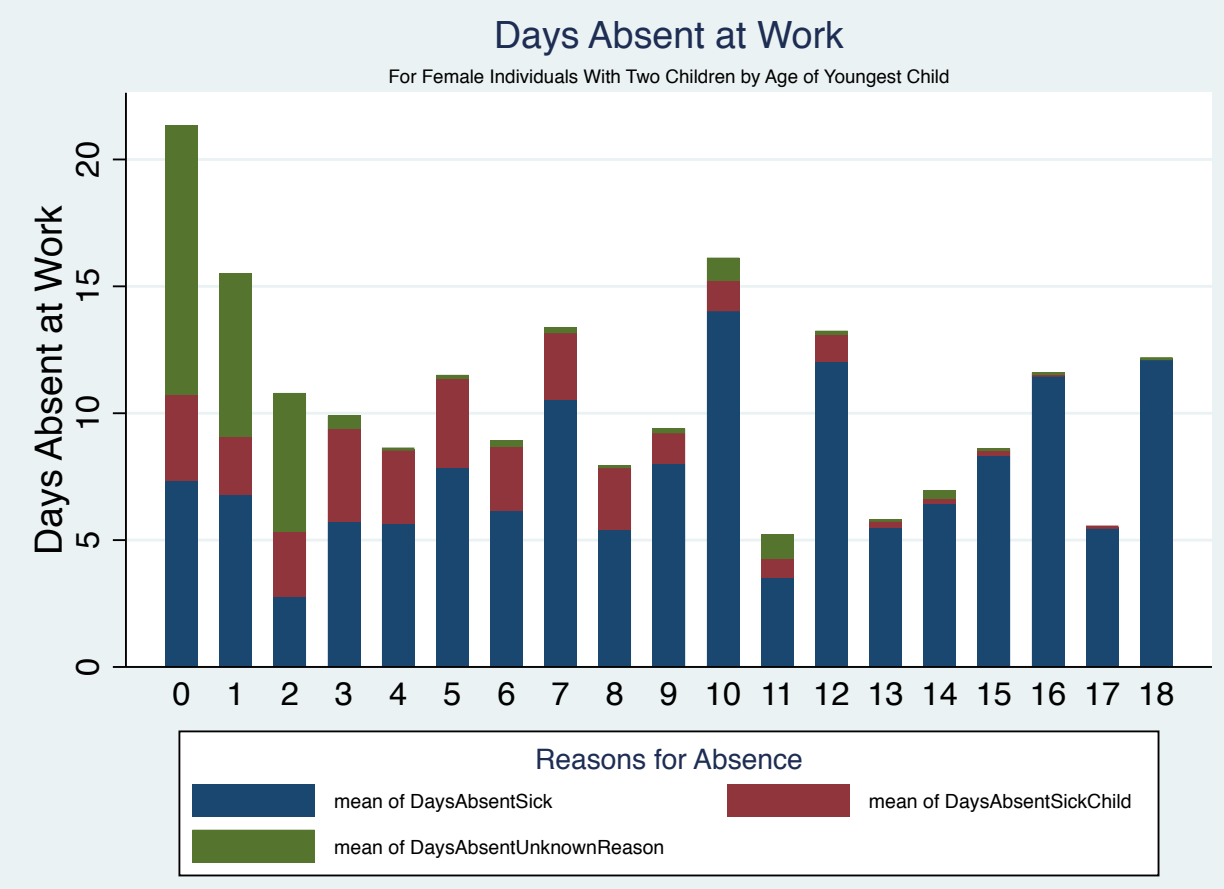

Days Absent at Work

For Male Individuals With Two Children by Age of Youngest Child

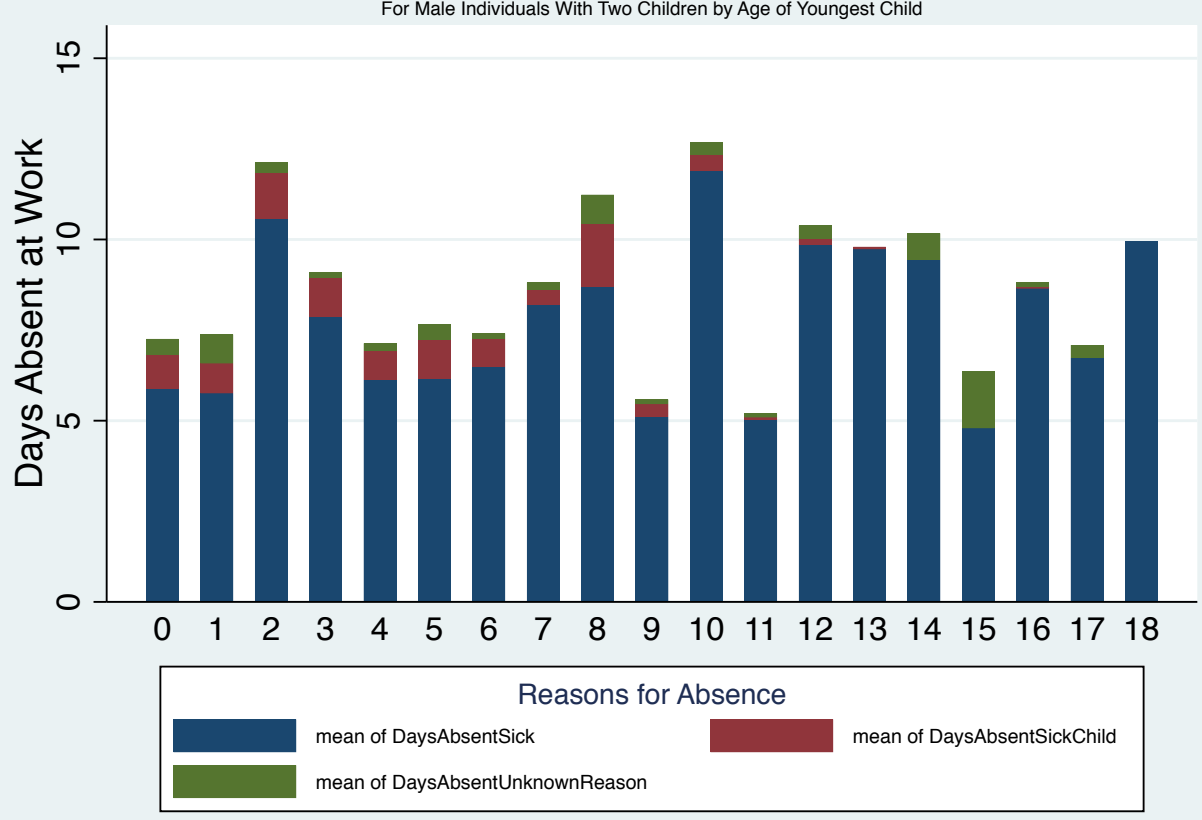

Notes: Data from Socio-Economic Panel (GSOEP). Displaying days absent from work in previous year. Reasons displayed are absences because of own sickness, absences because of sick child, and other/unknown reasons. 
Table 1: Callback rates

\begin{tabular}{|c|c|c|c|c|}
\hline \multirow[t]{2}{*}{ Full-time } & \multirow{2}{*}{$\begin{array}{c}\text { Women } \\
\begin{array}{c}\text { Callback rate } \\
\text { (in \%) }\end{array}\end{array}$} & \multicolumn{3}{|c|}{ Men } \\
\hline & & $\begin{array}{l}\text { Number of } \\
\text { observations }\end{array}$ & $\begin{array}{l}\text { Callback rate } \\
\quad \text { (in \%) }\end{array}$ & $\begin{array}{l}\text { Number of } \\
\text { observations }\end{array}$ \\
\hline All countries & 19.62 & 4245 & 11.53 & 2445 \\
\hline Germany & 20.82 & 2675 & 13.14 & 1621 \\
\hline Switzerland & 16.87 & 1156 & 9.07 & 562 \\
\hline Austria & 19.56 & 414 & 6.87 & 262 \\
\hline Accountants & 23.58 & 1887 & 16.72 & 1124 \\
\hline Secretaries & 16.45 & 2358 & 7.11 & 1321 \\
\hline Single No Kids & 20.58 & 933 & 11.89 & 429 \\
\hline Married No Kids & 19.42 & 937 & 9.62 & 405 \\
\hline Married 2 Young Kids & 18.36 & 719 & 12.41 & 588 \\
\hline $\begin{array}{l}\text { Married } 2 \text { Young Kids, No Statement } \\
\text { Family Completed }\end{array}$ & 17.61 & 636 & & \\
\hline $\begin{array}{l}\text { Married } 2 \text { Young Kids, Statement } \\
\text { Family Completed }\end{array}$ & 24.10 & 83 & & \\
\hline Married 2 Old Kids & 19.64 & 718 & 13.25 & 596 \\
\hline No Info on Family Status & 19.83 & 938 & 9.37 & 427 \\
\hline \multirow[t]{2}{*}{ Part-time } & Women & & Men & \\
\hline & $\begin{array}{l}\text { Callback rate } \\
\quad \text { (in \%) }\end{array}$ & $\begin{array}{l}\text { Number of } \\
\text { observations }\end{array}$ & $\begin{array}{l}\text { Callback rate } \\
\quad \text { (in } \% \text { ) }\end{array}$ & $\begin{array}{l}\text { Number of } \\
\text { observations }\end{array}$ \\
\hline All countries & 19.22 & 1332 & 7.26 & 647 \\
\hline Germany & 23.59 & 534 & 8.51 & 329 \\
\hline Switzerland & 15.44 & 693 & 6.43 & 280 \\
\hline Austria & 21.90 & 105 & 2.63 & 38 \\
\hline Accountants & 25.56 & 626 & 9.22 & 358 \\
\hline Secretaries & 13.60 & 706 & 4.84 & 289 \\
\hline Single No Kids & 18.77 & 293 & 8.11 & 111 \\
\hline Married No Kids & 13.11 & 305 & 5.77 & 104 \\
\hline Married 2 Young Kids & 20.70 & 256 & 8.12 & 160 \\
\hline $\begin{array}{l}\text { Married } 2 \text { Young Kids, No Statement } \\
\text { Family Completed }\end{array}$ & 21.83 & 229 & & \\
\hline $\begin{array}{l}\text { Married } 2 \text { Young Kids, Statement } \\
\text { Family Completed }\end{array}$ & 11.11 & 27 & & \\
\hline Married 2 Old Kids & 27.18 & 195 & 8.04 & 174 \\
\hline No Info on Family Status & 19.43 & 283 & 5.10 & 98 \\
\hline
\end{tabular}

Notes: The variable callback measures whether an applicant was invited for an interview. Data collected by the authors between March 2013 and June 2015 in a correspondence testing field experiment. Application packages consisted of a cover letter, a CV, language certificates, reference letters, as well as documents with degree and grade information. In all cases, two applications were sent to each company. We randomized the family status/composition, our treatment of interest, but also other elements in the CV such as the picture and name of the candidate as well as the general template of the application. (A template determined the general visual aspect of the application and was additionally tied in to a particular life story - birthplace, names of schools attended, jobs previously held, references, etc.). 
Table 2: Probability of a callback for females applying to full-time jobs, all countries (LPM)

\begin{tabular}{|c|c|c|c|c|c|c|c|c|}
\hline & $(1)$ & $(2)$ & $(3)$ & $(4)$ & (5) & $(6)$ & $(7)$ & $(8)$ \\
\hline \multirow[t]{2}{*}{ Married No Kids } & -0.012 & -0.012 & -0.011 & -0.011 & -0.011 & -0.011 & -0.014 & -0.014 \\
\hline & $(0.018)$ & $(0.018)$ & $(0.018)$ & $(0.018)$ & $(0.018)$ & $(0.018)$ & $(0.018)$ & $(0.018)$ \\
\hline \multirow[t]{2}{*}{ Married 2 Young Kids } & -0.022 & & -0.022 & & -0.026 & & -0.030 & \\
\hline & $(0.020)$ & & $(0.020)$ & & $(0.020)$ & & $(0.020)$ & \\
\hline \multicolumn{9}{|l|}{ Married 2 Young Kids, No Statement } \\
\hline \multirow[t]{2}{*}{ Family Completed } & & -0.030 & & -0.030 & & -0.033 & & $-0.038 *$ \\
\hline & & $(0.020)$ & & $(0.020)$ & & $(0.020)$ & & $(0.020)$ \\
\hline \multicolumn{9}{|l|}{ Married 2 Young Kids, Statement } \\
\hline \multirow[t]{2}{*}{ Family Completed } & & 0.035 & & 0.035 & & 0.031 & & 0.028 \\
\hline & & $(0.049)$ & & $(0.048)$ & & $(0.048)$ & & $(0.048)$ \\
\hline \multirow[t]{2}{*}{ Married 2 Old Kids } & -0.009 & -0.009 & -0.010 & -0.010 & -0.005 & -0.005 & -0.005 & -0.004 \\
\hline & $(0.020)$ & $(0.020)$ & $(0.020)$ & $(0.020)$ & $(0.020)$ & $(0.020)$ & $(0.020)$ & $(0.020)$ \\
\hline \multirow[t]{2}{*}{ No Info on Family Status } & -0.007 & -0.007 & -0.008 & -0.008 & -0.002 & -0.002 & -0.003 & -0.003 \\
\hline & $(0.019)$ & $(0.019)$ & $(0.019)$ & $(0.019)$ & $(0.019)$ & $(0.019)$ & $(0.019)$ & $(0.019)$ \\
\hline City Dummies & no & no & yes & yes & yes & yes & yes & yes \\
\hline Time Dummies (Year and Quarter) & no & no & no & no & yes & yes & yes & yes \\
\hline Application Characteristics & no & no & no & no & yes & yes & yes & yes \\
\hline Firm Characteristics & no & no & no & no & no & no & yes & yes \\
\hline \multirow[t]{2}{*}{ Constant } & $0.206 * * *$ & $0.206^{* * *}$ & $0.209 * * *$ & $0.209 * * *$ & $0.249 * * *$ & $0.251 * * *$ & $0.280 * * *$ & $0.282 * * *$ \\
\hline & $(0.014)$ & $(0.014)$ & $(0.031)$ & $(0.031)$ & $(0.045)$ & $(0.045)$ & $(0.060)$ & $(0.060)$ \\
\hline Observations & 4,245 & 4,245 & 4,245 & 4,245 & 4,245 & 4,245 & 4,233 & 4,233 \\
\hline R-squared & 0.000 & 0.001 & 0.014 & 0.015 & 0.034 & 0.034 & 0.041 & 0.041 \\
\hline
\end{tabular}

Robust standard errors in parentheses, ${ }^{* *}, \mathrm{p}<0.01,{ }^{* *} \mathrm{p}<0.05,{ }^{*} \mathrm{p}<0.1$

Notes: Data collected by the authors between March 2013 and June 2015 in a correspondence testing field experiment. The variable callback measures whether an applicant was invited for an interview. Standard errors are clustered at the company level. Controls are: City Dummies (Zurich, Basel, Hamburg, Berlin, Munich, Frankfurt, Cologne, Stuttgart, Vienna, Bern), Time Dummies (quarter as well as year dummies for when the application was sent), Application Characteristics (application template, individual picture used, occupation, quality of fit of the profile to vacancy, quality of application), Firm Characteristics (dummies for firm size, range of business activities (regional, national, international), sector of activity of the company (trade/wholesale, manufacturing, services, public sector), firm has antidiscrimination policy, distance from residence to the workplace). 
Table 3: Probability of a callback for females applying to part-time jobs, all countries (LPM)

\begin{tabular}{|c|c|c|c|c|c|c|c|c|}
\hline & $(1)$ & (2) & (3) & (4) & $(5)$ & $(6)$ & (7) & $(8)$ \\
\hline \multirow[t]{2}{*}{ Married No Kids } & $-0.057 *$ & $-0.057 *$ & -0.041 & -0.040 & -0.044 & -0.043 & $-0.052 *$ & $-0.052 *$ \\
\hline & $(0.030)$ & $(0.030)$ & $(0.030)$ & $(0.030)$ & $(0.030)$ & $(0.030)$ & $(0.030)$ & $(0.030)$ \\
\hline \multirow[t]{2}{*}{ Married 2 Young Kids } & 0.019 & & 0.037 & & 0.030 & & 0.021 & \\
\hline & $(0.035)$ & & $(0.035)$ & & $(0.035)$ & & $(0.034)$ & \\
\hline \multicolumn{9}{|l|}{ Married 2 Young Kids, No Statement } \\
\hline \multirow[t]{2}{*}{ Family Completed } & & 0.031 & & 0.049 & & 0.043 & & 0.032 \\
\hline & & $(0.037)$ & & $(0.036)$ & & $(0.036)$ & & $(0.036)$ \\
\hline \multicolumn{9}{|l|}{ Married 2 Young Kids, Statement } \\
\hline \multirow[t]{2}{*}{ Family Completed } & & -0.077 & & -0.066 & & -0.075 & & -0.069 \\
\hline & & $(0.065)$ & & $(0.066)$ & & $(0.065)$ & & $(0.065)$ \\
\hline \multirow[t]{2}{*}{ Married 2 Old Kids } & $0.084 * *$ & $0.084 * *$ & $0.092 * *$ & $0.092 * *$ & $0.080 * *$ & $0.081 * *$ & $0.082 * *$ & $0.082 * *$ \\
\hline & $(0.040)$ & $(0.040)$ & $(0.040)$ & $(0.040)$ & $(0.039)$ & $(0.039)$ & $(0.039)$ & $(0.039)$ \\
\hline \multirow[t]{2}{*}{ No Info on Family Status } & 0.007 & 0.007 & 0.008 & 0.008 & 0.002 & 0.003 & -0.008 & -0.007 \\
\hline & $(0.034)$ & $(0.034)$ & $(0.033)$ & $(0.033)$ & $(0.034)$ & $(0.034)$ & $(0.034)$ & $(0.034)$ \\
\hline City Dummies & no & no & yes & yes & yes & yes & yes & yes \\
\hline Time Dummies (Year and Quarter) & no & no & no & no & yes & yes & yes & yes \\
\hline Application Characteristics & no & no & no & no & yes & yes & yes & yes \\
\hline Firm Characteristics & no & no & no & no & yes & yes & yes & yes \\
\hline Observations & 1,332 & 1,332 & 1,332 & 1,332 & 1,332 & 1,332 & 1,327 & 1,327 \\
\hline R-squared & 0.012 & 0.013 & 0.050 & 0.052 & 0.083 & 0.085 & 0.102 & 0.103 \\
\hline
\end{tabular}

Robust standard errors in parentheses, ${ }^{* * *} \mathrm{p}<0.01, * * \mathrm{p}<0.05, * \mathrm{p}<0.1$

Notes: Data collected by the authors between March 2013 and June 2015 in a correspondence testing field experiment. The variable callback measures whether an applicant was invited for an interview. Standard errors are clustered at the company level. Controls are: City Dummies (Zurich, Basel, Hamburg, Berlin, Munich, Frankfurt, Cologne, Stuttgart, Vienna, Bern), Time Dummies (quarter as well as year dummies for when the application was sent), Application Characteristics (application template, individual picture used, occupation, quality of fit of the profile to vacancy, quality of application), Firm Characteristics (dummies for firm size, range of business activities (regional, national, international), sector of activity of the company (trade/wholesale, manufacturing, services, public sector), firm has antidiscrimination policy, distance from residence to the workplace). 
Table 4: Probability of a callback for females applying to part-time jobs by country, (LPM)

\begin{tabular}{|c|c|c|c|c|c|c|}
\hline & \multicolumn{2}{|c|}{ Germany } & \multicolumn{2}{|c|}{ Switzerland } & \multicolumn{2}{|c|}{ Austria } \\
\hline & $(1)$ & $(2)$ & $(3)$ & (4) & $(5)$ & $(6)$ \\
\hline Married No Kids & $\begin{array}{l}-0.094^{*} \\
(0.056)\end{array}$ & $\begin{array}{l}-0.093 * \\
(0.056)\end{array}$ & $\begin{array}{l}-0.032 \\
(0.036)\end{array}$ & $\begin{array}{l}-0.032 \\
(0.036)\end{array}$ & $\begin{array}{l}-0.104 \\
(0.136)\end{array}$ & $\begin{array}{l}-0.101 \\
(0.139)\end{array}$ \\
\hline Married 2 Young Kids & $\begin{array}{c}0.008 \\
(0.063)\end{array}$ & & $\begin{array}{c}0.040 \\
(0.044)\end{array}$ & & $\begin{array}{c}0.054 \\
(0.143)\end{array}$ & \\
\hline $\begin{array}{l}\text { Married } 2 \text { Young Kids, No Statement } \\
\text { Family Completed }\end{array}$ & & $\begin{array}{c}0.024 \\
(0.065)\end{array}$ & & $\begin{array}{c}0.048 \\
(0.046)\end{array}$ & & $\begin{array}{c}0.097 \\
(0.161)\end{array}$ \\
\hline $\begin{array}{l}\text { Married } 2 \text { Young Kids, Statement } \\
\text { Family Completed }\end{array}$ & & $\begin{array}{l}-0.134 \\
(0.119)\end{array}$ & & $\begin{array}{l}-0.037 \\
(0.078)\end{array}$ & & $\begin{array}{l}-0.080 \\
(0.209)\end{array}$ \\
\hline Married 2 Old Kids & $\begin{array}{c}0.092 \\
(0.068)\end{array}$ & $\begin{array}{c}0.094 \\
(0.068)\end{array}$ & $\begin{array}{c}0.072 \\
(0.051)\end{array}$ & $\begin{array}{c}0.072 \\
(0.051)\end{array}$ & $\begin{array}{c}0.136 \\
(0.150)\end{array}$ & $\begin{array}{c}0.136 \\
(0.150)\end{array}$ \\
\hline No Info on Family Status & $\begin{array}{l}-0.053 \\
(0.059)\end{array}$ & $\begin{array}{l}-0.052 \\
(0.060)\end{array}$ & $\begin{array}{c}0.027 \\
(0.046)\end{array}$ & $\begin{array}{c}0.027 \\
(0.046)\end{array}$ & $\begin{array}{c}0.049 \\
(0.140)\end{array}$ & $\begin{array}{c}0.055 \\
(0.141)\end{array}$ \\
\hline City Dummies & yes & yes & yes & yes & yes & yes \\
\hline Time Dummies (Year and Quarter) & yes & yes & yes & yes & yes & yes \\
\hline Application Characteristics & yes & yes & yes & yes & yes & yes \\
\hline Firm Characteristics & yes & yes & yes & yes & yes & yes \\
\hline Constant & $\begin{array}{c}0.222 \\
(0.186)\end{array}$ & $\begin{array}{c}0.219 \\
(0.186)\end{array}$ & $\begin{array}{l}0.193^{*} \\
(0.109)\end{array}$ & $\begin{array}{l}0.187^{*} \\
(0.109)\end{array}$ & $\begin{array}{l}-0.048 \\
(0.582)\end{array}$ & $\begin{array}{c}0.004 \\
(0.585)\end{array}$ \\
\hline Observations & 533 & 533 & 689 & 689 & 105 & 105 \\
\hline R-squared & 0.120 & 0.122 & 0.098 & 0.099 & 0.246 & 0.251 \\
\hline
\end{tabular}

Robust standard errors in parentheses, $* * * \mathrm{p}<0.01, * * \mathrm{p}<0.05, * \mathrm{p}<0.1$

Notes: Data collected by the authors between March 2013 and June 2015 in a correspondence testing field experiment. The variable callback measures whether an applicant was invited for an interview. Standard errors are clustered at the company level. Controls are: City Dummies (Zurich, Basel, Hamburg, Berlin, Munich, Frankfurt, Cologne, Stuttgart, Vienna, Bern), Time Dummies (quarter as well as year dummies for when the application was sent), Application Characteristics (application template, individual picture used, occupation, quality of fit of the profile to vacancy, quality of application), Firm Characteristics (dummies for firm size, range of business activities (regional, national, international), sector of activity of the company (trade/wholesale, manufacturing, services, public sector), firm has antidiscrimination policy, distance from residence to the workplace). 
Table 5: Decomposition results addressing the Heckman-Siegelman critique: Comparison of married women without children and married women with two old children

PART-TIME

All Countries

$0.129 * * *$

(0.033)

0.011

$(0.073)$

C. Decomposition

Marginal effect through level (unbiased)

$0.246^{* * *}$

(0.039)

$-0.234 * *$

(0.106)

FULL-TIME

All Countries

0.006

0.004

Marginal effect through variance

\begin{tabular}{llc}
\hline Standard deviation of unobservables: & \\
Married two old kids/Married no kids & 0.354 & 0.932 \\
Wald test statistics: & 0.001 & 0.830 \\
null hypothesis that ratio of standard deviations $=1$ (p-value) & 0.992 & 0.889 \\
Wald test statistic: null hypothesis that ratio of coefficients are equal & 477 & 1571 \\
\hline Number of observations &
\end{tabular}

Robust standard errors in parentheses, ${ }^{* * *}, \mathrm{p}<0.01, * * \mathrm{p}<0.05, * \mathrm{p}<0.1$

Notes: Data collected by the authors between March 2013 and June 2015 in a correspondence testing field experiment. The variable callback measures whether an applicant was invited for an interview. Standard errors are clustered at the company level. Controls are: Country Dummies (Germany, Switzerland, Austria), Time Dummies (quarter as well as year dummies for when the application was sent), Application Characteristics (application template, individual picture used, occupation, quality of fit of the profile to vacancy, quality of application), Firm Characteristics (dummies for firm size, range of business activities (regional, national, international), sector of activity of the company (trade/wholesale, manufacturing, services, public sector), firm has antidiscrimination policy, distance from residence to the workplace). 


\section{Appendix}

\section{Table A.1: Descriptive statistics}

Variables

Mean

Standard deviation

City Dummies

Application in Bern

0.067

0.250

Application in Zurich

0.202

0.401

Application in Basel

0.041

0.199

Application in Hamburg

0.106

0.307

Application in Berlin

0.175

0.380

Application in Munich

0.103

0.304

Application in Frankfurt

0.040

0.196

Application in Cologne

$0.100 \quad 0.299$

Application in Stuttgart

0.072

0.258

Application in Vienna

0.094

0.293

Time Dummies

Application sent in first quarter

Application sent in second quarter

pent in third quarter

0.283

0.450

Application sent in fourth quarter

0.407

Application sent in 2013

0.406

0.491

Application sent in 2014

0.517

0.500

Application sent in 2015

\section{Application Characteristics}

Application template

Male applicant

Female picture 1

Female picture 2

0.465

Male picture 1

Male picture 2

Advertisement for secretarial job

0.498

Applicant is good fit for advertised job ${ }^{\mathrm{a}}$

0.539

0.488

Applicant is average fit for advertised job ${ }^{b}$

0.480

Applicant is bad fit for advertised job

\section{Firm Characteristics}

Firm's business activities are local or regional

Firm's business activities are national

Firm's business activities are international

Firm has between 0 and 20 employees

Firm has between 21 and 50 employees

Firm has between 51 and 100 employees

$0.167 \quad 0.373$

Firm has between 101 and 250 employees

Firm has between 251 and 500 employees

Firm has between 501 and 1000 employees

Firm has more than 1000 employees

Firm in the Trade/Wholesale sector

Firm in the Manufacturing sector

Firm in the Service sector

Notes: $\mathrm{N}=8,669$, all variables take the value 0 or 1 .

Data collected by the authors between March 2013 and June 2015 in a correspondence testing field experiment.

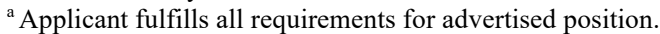

${ }^{\mathrm{b}}$ Applicant lacks only minor requirements for the advertised position.

${ }^{\mathrm{c}}$ Applicant lacks one major or two minor requirements for the advertised position.

${ }^{\mathrm{d}}$ Application does not include English and IT certificates.

${ }^{\mathrm{e}}$ An explicit antidiscrimination policy can be found on the company's website. 
Table A.2: Probability of a callback for females applying to full-time jobs by countries, (LPM)

\begin{tabular}{|c|c|c|c|c|c|c|}
\hline & \multicolumn{2}{|c|}{ Germany } & \multicolumn{2}{|c|}{ Switzerland } & \multicolumn{2}{|c|}{ Austria } \\
\hline & $(1)$ & (2) & $(3)$ & (4) & $(5)$ & $(6)$ \\
\hline \multirow[t]{2}{*}{ Married No Kids } & -0.013 & -0.013 & -0.019 & -0.018 & 0.032 & 0.032 \\
\hline & $(0.023)$ & $(0.023)$ & $(0.033)$ & $(0.033)$ & $(0.057)$ & $(0.057)$ \\
\hline \multirow[t]{2}{*}{ Married 2 Young Kids } & -0.024 & & -0.031 & & -0.018 & \\
\hline & $(0.026)$ & & $(0.035)$ & & $(0.056)$ & \\
\hline \multirow{3}{*}{$\begin{array}{l}\text { Married } 2 \text { Young Kids, No Statement } \\
\text { Family Completed }\end{array}$} & & & & & & \\
\hline & & -0.029 & & -0.040 & & -0.030 \\
\hline & & $(0.026)$ & & $(0.035)$ & & $(0.060)$ \\
\hline \multicolumn{7}{|l|}{ Married 2 Young Kids, Statement } \\
\hline \multirow[t]{2}{*}{ Family Completed } & & 0.019 & & 0.052 & & 0.033 \\
\hline & & $(0.064)$ & & $(0.099)$ & & $(0.095)$ \\
\hline \multirow[t]{2}{*}{ Married 2 Old Kids } & 0.001 & 0.001 & -0.039 & -0.039 & 0.093 & 0.093 \\
\hline & $(0.026)$ & $(0.026)$ & $(0.035)$ & $(0.036)$ & $(0.063)$ & $(0.063)$ \\
\hline \multirow[t]{2}{*}{ No Info on Family Status } & 0.005 & 0.005 & -0.031 & -0.031 & 0.054 & 0.054 \\
\hline & $(0.024)$ & $(0.024)$ & $(0.034)$ & $(0.034)$ & $(0.062)$ & $(0.062)$ \\
\hline City Dummies & yes & yes & yes & yes & yes & yes \\
\hline Time Dummies (Year and Quarter) & yes & yes & yes & yes & yes & yes \\
\hline Application Characteristics & yes & yes & yes & yes & yes & yes \\
\hline Firm Characteristics & yes & yes & yes & yes & yes & yes \\
\hline \multirow[t]{2}{*}{ Constant } & $0.319 * * *$ & $0.321 * * *$ & $0.414 * * *$ & $0.417 * * *$ & -0.020 & -0.021 \\
\hline & $(0.087)$ & $(0.087)$ & $(0.090)$ & $(0.090)$ & $(0.125)$ & $(0.125)$ \\
\hline Observations & 2,671 & 2,671 & 1,148 & 1,148 & 414 & 414 \\
\hline R-squared & 0.044 & 0.044 & 0.070 & 0.071 & 0.106 & 0.107 \\
\hline
\end{tabular}

Robust standard errors in parentheses, $* * * \mathrm{p}<0.01, * * \mathrm{p}<0.05, * \mathrm{p}<0.1$

Notes: Data collected by the authors between March 2013 and June 2015 in a correspondence testing field experiment. The variable callback measures whether an applicant was invited for an interview. Standard errors are clustered at the company level. Controls are: City Dummies (Zurich, Basel, Hamburg, Berlin, Munich, Frankfurt, Cologne, Stuttgart, Vienna, Bern), Time Dummies (quarter as well as year dummies for when the application was sent), Application Characteristics (application template, individual picture used, occupation, quality of fit of the profile to vacancy, quality of application), Firm Characteristics (dummies for firm size, range of business activities (regional, national, international), sector of activity of the company (trade/wholesale, manufacturing, services, public sector), firm has antidiscrimination policy, distance from residence to the workplace). 
Table A.3: Probability of a callback for males applying to full-time jobs by country, (LPM)

\begin{tabular}{|c|c|c|c|c|c|c|c|c|}
\hline & \multicolumn{2}{|c|}{ All Countries } & \multicolumn{2}{|c|}{ Germany } & \multicolumn{2}{|c|}{ Switzerland } & \multicolumn{2}{|c|}{ Austria } \\
\hline & $(1)$ & $(2)$ & $(3)$ & (4) & $(5)$ & (6) & $(7)$ & $(8)$ \\
\hline Married No Kids & $\begin{array}{l}-0.023 \\
(0.022)\end{array}$ & $\begin{array}{l}-0.023 \\
(0.022)\end{array}$ & $\begin{array}{l}-0.041 \\
(0.030)\end{array}$ & $\begin{array}{l}-0.045 \\
(0.029)\end{array}$ & $\begin{array}{c}0.014 \\
(0.043)\end{array}$ & $\begin{array}{c}0.028 \\
(0.041)\end{array}$ & $\begin{array}{c}0.002 \\
(0.048)\end{array}$ & $\begin{array}{l}-0.024 \\
(0.056)\end{array}$ \\
\hline Married 2 Young Kids & $\begin{array}{c}0.005 \\
(0.021)\end{array}$ & $\begin{array}{c}0.001 \\
(0.021)\end{array}$ & $\begin{array}{l}-0.010 \\
(0.028)\end{array}$ & $\begin{array}{l}-0.014 \\
(0.028)\end{array}$ & $\begin{array}{c}0.048 \\
(0.043)\end{array}$ & $\begin{array}{c}0.059 \\
(0.042)\end{array}$ & $\begin{array}{l}-0.022 \\
(0.042)\end{array}$ & $\begin{array}{l}-0.040 \\
(0.048)\end{array}$ \\
\hline Married 2 Old Kids & $\begin{array}{c}0.014 \\
(0.021)\end{array}$ & $\begin{array}{c}0.014 \\
(0.021)\end{array}$ & $\begin{array}{c}0.014 \\
(0.028)\end{array}$ & $\begin{array}{c}0.015 \\
(0.028)\end{array}$ & $\begin{array}{c}0.002 \\
(0.037)\end{array}$ & $\begin{array}{c}0.001 \\
(0.038)\end{array}$ & $\begin{array}{c}0.019 \\
(0.048)\end{array}$ & $\begin{array}{c}0.002 \\
(0.052)\end{array}$ \\
\hline No Info on Family Status & $\begin{array}{l}-0.025 \\
(0.022)\end{array}$ & $\begin{array}{l}-0.026 \\
(0.021)\end{array}$ & $\begin{array}{l}-0.030 \\
(0.030)\end{array}$ & $\begin{array}{l}-0.028 \\
(0.029)\end{array}$ & $\begin{array}{l}-0.056^{*} \\
(0.033)\end{array}$ & $\begin{array}{l}-0.050 \\
(0.034)\end{array}$ & $\begin{array}{c}0.055 \\
(0.052)\end{array}$ & $\begin{array}{c}0.052 \\
(0.055)\end{array}$ \\
\hline $\begin{array}{l}\text { City Dummies } \\
\text { Time Dummies }\end{array}$ & no & yes & no & yes & no & yes & no & yes \\
\hline (Year and Quarter) & no & yes & no & yes & no & yes & no & yes \\
\hline Application Characteristics & no & yes & no & yes & no & yes & no & yes \\
\hline Firm Characteristics & no & yes & no & yes & no & yes & no & yes \\
\hline Constant & $\begin{array}{c}0.119 * * * \\
(0.016)\end{array}$ & $\begin{array}{c}0.148 * * \\
(0.058)\end{array}$ & $\begin{array}{c}0.142 * * * \\
(0.023)\end{array}$ & $\begin{array}{c}0.158 \\
(0.098)\end{array}$ & $\begin{array}{c}0.087 * * * \\
(0.028)\end{array}$ & $\begin{array}{c}0.199 * * \\
(0.083)\end{array}$ & $\begin{array}{l}0.059 * \\
(0.033)\end{array}$ & $\begin{array}{c}0.086 \\
(0.080)\end{array}$ \\
\hline Observations & 2,445 & 2,440 & 1,621 & 1,620 & 562 & 558 & 262 & 262 \\
\hline R-squared & 0.002 & 0.044 & 0.003 & 0.046 & 0.013 & 0.092 & 0.009 & 0.111 \\
\hline
\end{tabular}

Robust standard errors in parentheses, $* * * \mathrm{p}<0.01, * * \mathrm{p}<0.05, * \mathrm{p}<0.1$

Notes: Data collected by the authors between March 2013 and June 2015 in a correspondence testing field experiment. The variable callback measures whether an applicant was invited for an interview. Standard errors are clustered at the company level. Controls are: City Dummies (Zurich, Basel, Hamburg, Berlin, Munich, Frankfurt, Cologne, Stuttgart, Vienna, Bern), Time Dummies (quarter as well as year dummies for when the application was sent), Application Characteristics (application template, individual picture used, occupation, quality of fit of the profile to vacancy, quality of application), Firm Characteristics (dummies for firm size, range of business activities (regional, national, international), sector of activity of the company (trade/wholesale, manufacturing, services, public sector), firm has antidiscrimination policy, distance from residence to the workplace). 